\title{
Evaluation of the Sildenafil Effect on Female Sexual Dysfunction
}

\author{
Abdalla H. Kandil, Elsayed M. Galal, Amina M. Shawqy
}

\author{
Original Department of Dermatology, Venereology \& Andrology, Faculty of Medicine, Zagazig \\ Article University, Zagazig, Egypt
}

\begin{abstract}
Background : Female Sexual Dysfunction (FSD) is a disturbance or dysfunction in the process of desire, arousal or orgasm which can be a symptom of a biological condition, a psychological problem or an interpersonal issue or a combination of these factors. Female Sexual Dysfunction is a multi-causal and a multi-dimensional medical problem that adversely affects physical health \& emotional wellbeing. Also impaired sexual function has damaging effects on the self esteem, sense of wholeness and interpersonal relationships of women. It is often emotionally distressing and might lead to familial discord and divorce, and reproduction is also affected. Sildenafil is selective type 5 phosphodiesterase (PDE5) inhibitors, taken orally and effective for men with erectile dysfunction. Previous studies suggested that sildenafil, which acts by inhibiting cyclic GMP specific PDE5, may improve the sexual health of women affected by sexual difficulties such as arousal disorders and may indirectly improve other aspects of sexual life. Sildenafil was effective and well tolerated in post menopausal women with sexual arousal disorder without concomitant hypoactive sexual desire disorder or contributory emotional relationship or historical abuse issues.

Objective: This study aims to evaluate the effect of sildenafil citrate on female sexual dysfunction.

Subjects and Methods: The study was conducted in Dermatology,Venereology, and Andrology department, Faculty of Medicine, Zagazig University Hospitals during the period from April 2015 to August 2016. Twenty six married female patients were included in this study. Patients were divided into two groups. Group 1 contains thirteen patients took $50 \mathrm{mg}$ sildenafil on demand and group 2 contains thirteen patients took placebo.

Results: There was no significant differences between the studied groups regarding the demographic data, and FSFI scors. There was significant differences between pre and post treatment of sexual dysfunction scors regarding group I. There was no significant differences in post treatment results between the two studied groups as regard sexual dysfunction except in orgasm and pain.

Conclusions: Sildenafil citrate may be effective in women who couldn't achieve orgasm and decrease pain in patients with dysparunia.
\end{abstract}

Key Words: Female, sexual dysfunction, sildenafil.

Received: 17 June 2017, Accepted: 20 July 2017

Corresponding Author: Abdalla Kandi, Tel.: 01026530351, E-mail: ak.kandil@hotmail.com

ISSN: 2090-6048, September 2017, Vol. 7, No. 3

\section{INTRODUCTION}

Sex is one of the basic drives. Impairment of sexual function can has aprofound effect on the quality and other aspects of life. Sexual behavior is a complex and interesting interaction of central\& peripheral nervous system, modified by various psychological and physical factors ${ }^{[1]}$.

Sexual act is coordinated by neurological, vascular, and endocrine systems. Sexual activity can be negatively affected by any kind of stress or emotional disorder. Lack of information on the sexual function and pathophysiology of sexual dysfunction (SD) may lead to long lasting (primary SD) or the activities would return to normal after a period of time(secondary SD). It may be general or conditional (i.e. related to a specific person or situation). It may be caused by psychological factors or a combination of factors ${ }^{[2]}$.

Female Sexual Dysfunction(FSD) is a disturbance or dysfunction in the process of desire, arousal or orgasm which can be a symptom of a biological condition, a 
psychological problem or an interpersonal issue or a combination of these factors ${ }^{[3]}$.

Female Sexual Dysfunction is a multi-causal and a multi-dimensional medical problem that adversely affects physical health \& emotional wellbeing. Also impaired sexual function can has damaging effects on the self esteem, sense of wholeness and interpersonal relationships of women. It is often emotionally distressing and might lead to familial discord and divorce, and reproduction is also affected ${ }^{[4]}$.

Selective type 5 phosphodiesterase (PDE5) inhibitors as sidenafil, which acts by inhibiting cyclic GMP specific PDE5 effective for men with erectile dysfunction, may improve the sexual health of women affected by sexual difficulties such as arousal disorders and may indirectly improve other aspects of sexual life. ${ }^{[5]}$.

Sildenafil was effective and well tolerated in post menopausal women with sexual arousal disorder without concomitant hypoactive sexual desire disorder or contributory emotional relationship or historical abuse issues $^{[6]}$

\section{PATIENTS AND METHODS}

The study was conducted in Department of Dermatology, Venereology, and Andrology department, Faculty of Medicine, Zagazig University Hospitals during the period from April 2015 to August 2016. Twenty six married female patients were included in this study. Consents were taken from the patients. Patients were divided into two groups. Group 1 contains thirteen patients took $50 \mathrm{mg}$ sildenafil on demand and group 2 contains thirteen patients took placebo.

Ethical approval for this study (Institutional Review Board $\left.\mathrm{N}^{\circ} 1965\right)$ was provided by the Institutional Review Board (IRB) for Faculty of Medicine, Zagazig University, Zagazig, Egypt on March 30, 2015.

Inclusion criteria: Married female patients complaining of sexual dysfunction more than 6 months and not on drug therapy for the treatment of FSD.

Exclusion criteria: Patients with sexual dysfunction caused by localized disorders, patients with retinal problem, patients with chronic debilitating diseases or hormonal disturbance, patients cannot be treated with PDEs inhibitors type 5(sildenafil) as: Major hematological, renal or hepatic abnormalities, patients with major psychological disorders including major depression or psychosis, a history of stroke or myocardial infarction or any significant cardiovascular disease within the last 6 months, or concomitant treatment with nitrates.

Methods and objectives: All patients in the 2 groups were subjected to: Complete history taking: age, education, occupation, residence, age of marriage, special habits, history of medical diseases, surgical history and sexual history in the previous 6 months. General and physical examination: pulse, blood pressure, routine laboratory investigations including complet blood count, liver function tests, renal function tests, blood sugar and lipid profils. Fundus examination. Evaluation questionnaire used included 25 items designed by the investigators. Only some items were selected from the female sexual function index $(\mathrm{FSFI})^{[7]}$,other questions were added to suit the purpose of study.

The FSFI domain has a maximum possible total scores of 36 as in (Table 1). The FSFI, a 19-item questionnaire, has been developed as a brief, multidimensional selfreport instrument for assessing the key dimensions of sexual function in women. It is psychometrically sound, easy to administer, and has demonstrated ability to discriminate between clinical and nonclinical populations. The questionnaire described was designed and validated for assessment of female sexual function and quality of life in clinical trials or epidemiological studies.

Also depression questionnaire was added to exclude the major psychological depressive disorder and its result put with the evaluation questionnaire as one item only as in (Table 2).

The included patients classified into two groups: Group I:13 patients with FSD received $50 \mathrm{mg}$ sildenafil on empty stomach at need as oral dose for 2 months, Group II:13 patients with FSD received placebo tablets at need as oral dose for 2 months.

Statistical Analysis: The collected data were computerized and statistically analyzed using SPSS program (Statistical Package for Social Science) version 18.0. SPSS Inc., Chicago, IL,US.

\section{RESULTS}

No significant differences between the studied groups regarding the demographic data (Table 3 ), and FSFI scors (Table 4). There was significant differences between pre and post treatment of sexual dysfunction scors regarding group I (Table 5). There was no significant differences in post treatment results between the two studied groups as regard sexual dysfunction except in orgasm and pain (Table 6). 
Table 1: The individual domain scores and full scale scor of FSFI

\begin{tabular}{|c|c|c|c|c|c|c|}
\hline Domain & Questions & Score Range & Factor & Minimum Score & Maximum Score & Score \\
\hline Desire & 1,2 & $1-5$ & 0.6 & 1.2 & 6.0 & \\
\hline Arousal & $3,4,5,6$ & $0-5$ & 0.3 & 0 & 6.0 & \\
\hline Lubrication & $7,8,9,10$ & $0-5$ & 0.3 & 0 & 6.0 & \\
\hline Orgasm & $11,12,13$ & $0-5$ & 0.4 & 0 & 6.0 & \\
\hline Satisfaction & $14,15,16$ & $0($ or 1$)-5$ & 0.4 & 0.8 & 6.0 & \\
\hline Pain & $17,18,19$ & $0-5$ & 0.4 & 0 & 6.0 & \\
\hline \multicolumn{4}{|c|}{ Full Score Range } & 2.0 & 36.0 & \\
\hline
\end{tabular}

The female sexual function index (FSFI) (Rosen et al., 2000).

Table 2: The total score of PHQ-9 done as following:

\begin{tabular}{lc}
\hline Total score & Depression severity \\
\hline $1-4$ & Minimal depression \\
$5-9$ & Mild depression \\
$10-14$ & Moderate depression \\
$15-19$ & Moderate severe depression \\
$20-27$ & Severe depression \\
\hline
\end{tabular}

Table 3: comparison between the studied groups regarding demographic data.

\begin{tabular}{|c|c|c|c|c|}
\hline Demographic data & $\begin{array}{l}\text { Group I } \\
(\mathrm{N}=13)\end{array}$ & $\begin{array}{c}\text { Group II } \\
(\mathrm{N}=13)\end{array}$ & Test & $\begin{array}{c}\text { p-value } \\
\text { (sig.) }\end{array}$ \\
\hline \multicolumn{5}{|l|}{ Age (years) } \\
\hline Mean \pm SD & $29.30 \pm 6.82$ & & $0.584 *$ & 0.584 \\
\hline Median (Range) & $29(19-42)$ & & & $(\mathrm{NS})$ \\
\hline \multicolumn{5}{|l|}{ Education } \\
\hline \multirow[t]{2}{*}{ Secondary } & $8(61.5 \%)$ & & & 0.116 \\
\hline & & & $2.476 \div$ & $(\mathrm{NS})$ \\
\hline University & $5(38.5 \%)$ & & & \\
\hline \multicolumn{5}{|l|}{ Job } \\
\hline \multirow[t]{2}{*}{ Not work } & $6(46.2 \%)$ & $3(23.1 \%)$ & & 0.411 \\
\hline & & & $1.529 \%$ & (NS) \\
\hline Work & $7(53.8 \%)$ & $10(76.9 \%)$ & & \\
\hline
\end{tabular}




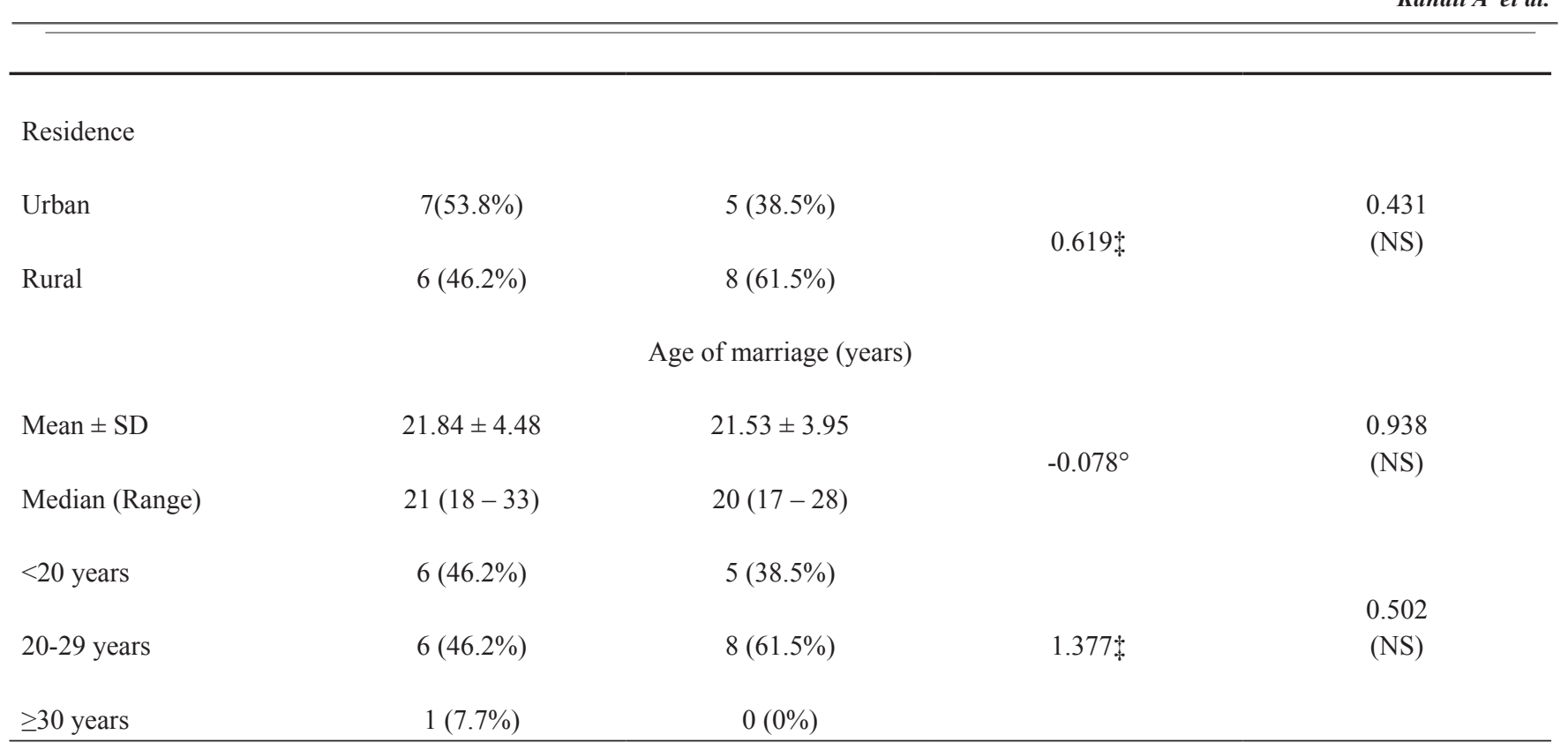

* Independent samples Student's t-test. ${ }^{\circ}$ Mann Whitney U test. + Chi-square test. $p<0.05$ is significant. Sig.: significance.

Table 4 : comparison between the studied groups regarding pre-treatment female sexual function index scores.

\begin{tabular}{|c|c|c|c|c|}
\hline $\begin{array}{l}\text { Pre-treatment female } \\
\text { sexual function index } \\
\text { scores }\end{array}$ & $\begin{array}{l}\text { Group I } \\
(\mathrm{N}=13)\end{array}$ & $\begin{array}{c}\text { Group II } \\
(\mathrm{N}=13)\end{array}$ & Test $^{\circ}$ & $\begin{array}{l}\text { p-value } \\
\text { (Sig.) }\end{array}$ \\
\hline \multicolumn{5}{|l|}{ Desire score } \\
\hline Mean $\pm \mathrm{SD}$ & $1.92 \pm 1.25$ & $2.30 \pm 0.94$ & \multirow{2}{*}{-1.153} & \multirow[t]{2}{*}{$\begin{array}{c}0.249 \\
(\mathrm{NS})\end{array}$} \\
\hline Median (Range) & $1(1-4)$ & $2(1-4)$ & & \\
\hline \multicolumn{5}{|l|}{ Arousal score } \\
\hline Mean $\pm \mathrm{SD}$ & $2.30 \pm 1.03$ & $2.53 \pm 1.12$ & \multirow[t]{2}{*}{-0.774} & \multirow[t]{2}{*}{$\begin{array}{c}0.439 \\
(\mathrm{NS})\end{array}$} \\
\hline Median (Range) & $2(1-4)$ & $3(0-4)$ & & \\
\hline \multicolumn{5}{|l|}{ Lubrication score } \\
\hline Mean $\pm \mathrm{SD}$ & $2.15 \pm 1.28$ & $2.38 \pm 1.19$ & \multirow{2}{*}{-0.672} & \multirow[t]{2}{*}{$\begin{array}{c}0.502 \\
(\mathrm{NS})\end{array}$} \\
\hline Median (Range) & $2(0-4)$ & $3(0-4)$ & & \\
\hline \multicolumn{5}{|l|}{ Orgasm score } \\
\hline Mean \pm SD & $1.53 \pm 0.66$ & $1.46 \pm 0.77$ & \multirow[b]{2}{*}{0.27} & \multirow[b]{2}{*}{0.27} \\
\hline Median (Range) & $2(0-2)$ & $2(0-2)$ & & \\
\hline
\end{tabular}


Satisfaction score

Mean \pm SD

Median (Range)

Pain score

Mean \pm SD

$3.46 \pm 1.66$

$4(1-5)$

Median (Range)

Full Score

Mean \pm SD

$12.84 \pm 5.36$

$13(4-23)$

Median (Range)
$1.61 \pm 1.44$

$-0.294$

0.768

$1(0-4)$

$3.53 \pm 1.33$

$-0.185$

0.853

$4(1-5)$

$13.84 \pm 4.81$

$-0.50$

0.62

(NS)

$16(4-19)$

Table 5: Comparison between pre-treatment and post-treatment female sexual function index scores in group 1.

\begin{tabular}{|c|c|c|c|c|}
\hline \multirow{2}{*}{$\begin{array}{l}\text { Female sexual function } \\
\text { index scores }\end{array}$} & \multicolumn{2}{|c|}{ Sildenafil group } & \multirow{2}{*}{ Test } & \multirow{2}{*}{$\begin{array}{l}\text { p-value } \\
\text { (Sig.) }\end{array}$} \\
\hline & $\begin{array}{l}\text { Pre-treatment } \\
\qquad(\mathrm{N}=13)\end{array}$ & $\begin{array}{l}\text { Post-treatment } \\
(\mathrm{N}=13)\end{array}$ & & \\
\hline \multicolumn{5}{|l|}{ Desire score } \\
\hline Mean \pm SD & $1.92 \pm 1.25$ & $3 \pm 0.81$ & $-2.640^{\circ}$ & $\begin{array}{l}0.008 \\
(\mathrm{~S})\end{array}$ \\
\hline Median (Range) & $1(1-4)$ & $3(1-4)$ & & \\
\hline \multicolumn{5}{|l|}{ Arousal score } \\
\hline Mean \pm SD & $2.30 \pm 1.03$ & $3.07 \pm 0.75$ & $-2.456^{\circ}$ & $\begin{array}{l}0.014 \\
(\mathrm{~S})\end{array}$ \\
\hline Median (Range) & $2(1-4)$ & $3(2-4)$ & & \\
\hline \multicolumn{5}{|l|}{ Lubrication score } \\
\hline Mean \pm SD & $2.15 \pm 1.28$ & $3 \pm 0.81$ & $-2.232^{\circ}$ & $\begin{array}{l}0.026 \\
(\mathrm{~S})\end{array}$ \\
\hline Median (Range) & $2(0-4)$ & $3(2-4)$ & & \\
\hline \multicolumn{5}{|l|}{ Orgasm score } \\
\hline Mean \pm SD & $1.53 \pm 0.66$ & $2.23 \pm 0.83$ & $-3.95^{\circ}$ & $\begin{array}{l}0.002 \\
(\mathrm{~S})\end{array}$ \\
\hline Median (Range) & $2(0-2)$ & $2(1-4)$ & & \\
\hline Satisfaction score & & & & \\
\hline
\end{tabular}




\begin{tabular}{|c|c|c|c|c|}
\hline Mean \pm SD & $1.46 \pm 1.50$ & $2.84 \pm 0.89$ & \multirow[t]{2}{*}{$-2.404^{\circ}$} & \multirow[t]{2}{*}{$\begin{array}{l}0.016 \\
\text { (S) }\end{array}$} \\
\hline Median (Range) & $1(0-4)$ & $3(0-4)$ & & \\
\hline \multicolumn{5}{|l|}{ Pain score } \\
\hline Mean \pm SD & $3.46 \pm 1.66$ & $4.61 \pm 0.65$ & \multirow[t]{2}{*}{$-2.200^{\circ}$} & \multirow[t]{2}{*}{$\begin{array}{l}0.028 \\
\text { (S) }\end{array}$} \\
\hline Median (Range) & $4(1-5)$ & $5(3-5)$ & & \\
\hline \multicolumn{5}{|l|}{ Full Score } \\
\hline Mean \pm SD & $12.84 \pm 5.36$ & $18.76 \pm 2.16$ & \multirow[t]{2}{*}{$4.27^{*}$} & \multirow[t]{2}{*}{$\begin{array}{l}0.001 \\
(\mathrm{~S})\end{array}$} \\
\hline Median (Range) & $13(4-23)$ & $19(15-22)$ & & \\
\hline
\end{tabular}

${ }^{\circ}$ Wilcoxon signed ranks test. * Paired t-test. $\mathrm{p}<0.05$ is significant.Sig.: significance.

The table showing significant difference between the sildenafil group pre- and post-treatment as regard all items of FSFI.

Table 6: Comparison between the studied groups regarding post-treatment female sexual function index scores

\begin{tabular}{|c|c|c|c|c|}
\hline $\begin{array}{l}\text { Post-treatment female } \\
\text { sexual function index } \\
\text { scores }\end{array}$ & $\begin{array}{l}\text { Group I } \\
(\mathrm{N}=13)\end{array}$ & $\begin{array}{l}\text { Group II } \\
(\mathrm{N}=13)\end{array}$ & Test $^{\circ}$ & $\begin{array}{c}\text { p-value } \\
\text { (Sig.) }\end{array}$ \\
\hline \multicolumn{5}{|l|}{ Desire score } \\
\hline Mean $\pm \mathrm{SD}$ & $3 \pm 0.81$ & $2.84 \pm 0.68$ & \multirow[t]{2}{*}{-0.692} & \multirow[t]{2}{*}{$\begin{array}{l}0.489 \\
\text { (NS) }\end{array}$} \\
\hline Median (Range) & $3(1-4)$ & $3(1-4)$ & & \\
\hline \multicolumn{5}{|l|}{ Arousal score } \\
\hline Mean \pm SD & $3.07 \pm 0.75$ & $3.23 \pm 0.59$ & \multirow[t]{2}{*}{-0.512} & \multirow[t]{2}{*}{$\begin{array}{l}0.609 \\
\text { (NS) }\end{array}$} \\
\hline Median (Range) & $3(2-4)$ & $3(2-4)$ & & \\
\hline \multicolumn{5}{|l|}{ Lubrication score } \\
\hline Mean \pm SD & $3 \pm 0.81$ & $3.07 \pm 0.64$ & \multirow[t]{2}{*}{-0.251} & \multirow[t]{2}{*}{$\begin{array}{c}0.802 \\
\text { (NS) }\end{array}$} \\
\hline Median (Range) & $3(2-4)$ & $3(2-4)$ & & \\
\hline \multicolumn{5}{|l|}{ Orgasm score } \\
\hline Mean \pm SD & $2.23 \pm 0.83$ & $1.53 \pm 0.66$ & \multirow{2}{*}{2.35} & \multirow{2}{*}{$\begin{array}{c}0.027 \\
(\mathrm{~S})\end{array}$} \\
\hline Median (Range) & $2(1-4)$ & $2(0-2)$ & & \\
\hline \multicolumn{5}{|l|}{ Satisfaction score } \\
\hline Mean \pm SD & $2.84 \pm 0.89$ & $2.46 \pm 1.45$ & \multirow[t]{2}{*}{-0.395} & \multirow[t]{2}{*}{$\begin{array}{l}0.693 \\
\text { (NS) }\end{array}$} \\
\hline Median (Range) & $3(0-4)$ & $3(0-4)$ & & \\
\hline
\end{tabular}




\begin{tabular}{|c|c|c|c|c|}
\hline Pain score & & & \multirow{3}{*}{-2.126} & \multirow{3}{*}{$\begin{array}{r}0.033 \\
(\mathrm{~S})\end{array}$} \\
\hline Mean $\pm \mathrm{SD}$ & $4.61 \pm 0.65$ & $5 \pm 0$ & & \\
\hline Median (Range) & $5(3-5)$ & $5(5-5)$ & & \\
\hline \multicolumn{5}{|l|}{ Full Score } \\
\hline Mean $\pm \mathrm{SD}$ & $18.76 \pm 2.16$ & $18.15 \pm 2.26$ & \multirow[t]{2}{*}{0.708} & \multirow[t]{2}{*}{$\begin{array}{l}0.48 \\
(\mathrm{NS})\end{array}$} \\
\hline Median (Range) & $19(15-22)$ & $18(15-22)$ & & \\
\hline
\end{tabular}

\section{DISCUSSION}

Sexual dysfunction is defined as a disturbance in sexual response cycle $^{[8]}$. Female sexual problems haven't received much attention as men sexual problems especially in Arab countries. This may be due to cultural and religious values, inadequate sex education, restricted discussion with health professionals about sexual problems, and feelings of embarrassment may complicate women's chances of receiving help and consultation from healthcare providers ${ }^{[9]}$.

The current study was conducted to evaluate the effect of sildenafil citrate on the female sexual dysfunction. The included sample was composed of 26 women complain of sexual dysfunction and divided in two equal groups. 13 women in group I who received sildenafil citrate $50 \mathrm{mg}$ for 2 months, and 13 women in group II who received placebo. All patients were evaluated with detailed medical and sexual history, including FSFI and depresion questionnaire.

Overall, most of patients who received sildenafil were living in urban areas $(53 \%)$. All patients of this study were educated variant between secondary and university levels those have more accurate results, due to an association between formal education and the desire and ability to obtain extra information through the media, which are more accessible in cities than in rural areas. There was no variety among studied groups regarding the pre-treatment sexual function assessment with its all items.

In the present study, there is improvement in sexual dysfunction in group1, the improvement occurred in desire, maintenance of lubrication, orgasm and satisfaction, as significant differences in all items of FSFI scores of the group 1 treated with sildenafil where the more prominent in desire and orgasm, as significant change of mean desire in pre and post treatment $(1.92 \pm$ $1.25)$ VS $(3 \pm 0.81)$, and the mean orgasm score between the same group $(1.53 \pm 0.66) \mathrm{VS}(2.23 \pm 0.83)$ in pre and post treatment, respectively.
The improvnent in all items of FSFI score in group1 may be related to increase in androgen level as there is a positive correlation between sildenafil intake and increase testosterone blood level ${ }^{[10]}$, also it increase the pelvic blood supply which may give more improvement in lubrication and decrease pain during sexual act and decrease overall sexual satisfaction.

These results supported by the study carried by Leddy et al. ${ }^{[11]}$ as thirteen of $19(68 \%)$ subjects achieved a $\geq 50 \%$ increase in clitoral engorgement from baseline when administered sildenafil or placebo 30 minutes after dose administration. At 60 minutes after administration, $17 / 19(89 \%)$ subjects receiving sildenafil and 16 $/ 19$ (84\%) subjects receiving placebo had responded $(P$ value 0.3173$)$.

However Lo Monte et al., ${ }^{[12]}$ stated that all the studies confirm $\neg$ ing the positive results of sildenafil, the drug proved to be more effective in the genital subgroup. It can be speculated that sildenafil citrate only acts on the physical phenomena of arousal and does not completely respond to the complex $\neg$ ity of FSAD. In fact, encouraging results were achieved in specific groups of patients affected by secondary FSADs (eg, diabetes mellitus, multiple sclerosis, chronic antidepressant users) in which the genital arousal disorder is clearly con $\neg$ nected with a neurological or vascular injury ${ }^{[5]}$.

These results were opposite to the study of Desgupta et al., ${ }^{[13]}$ in which statistically significant improvement following sildenafil was only reported in the lubrication domain of sexual function and there was no overall change in quality of life after sildenafil. Also Kaplan et al., ${ }^{[14]}$, reported only lubrication changes in vaginal and clitoral sensitivity in patients treated with sildenafil.

When examining the effects of sildenafil on female sexual dysfunction, it was found that sildenafil may increase congestion of the vagina, but it has no effect on excitement. This difference in results can be attributed to the manner and extent of drug administration, assessment of sexual status, and cultural status of the subjects in the 
study. Moreover, in most studies, the sample size has been very small, which makes their validity questionable.

Also these results were also oppose the results of the study of Berman et al. ${ }^{[6]}$ as efficacy was shown on only one sexual function measure and only in a small subsample of women who had no associated hypoactive sexual desire disorder and had sufficient estradiol and free testosterone concentration. Proposed reasons for the unconvincing efficacy of sildenafil in women have included failure to adequately characterize the study populations, differences in the physiologic response to sildenafil. It is also possible that lack of concordance between physiological and subjective aspects of women's sexual experiences need to be further investigated parallel with our results.

In the present study the post treatment comparison between the studied groups regarding female sexual function index scores, non significant differences between both groups except in pain and orgasm scores where some improvement occurred in sildenafile than in placebo group.

Finally we can coclude that the sildenafil is effective in treatment of female sexual dysfunction. As it improves orgasm, and decrease pain.

\section{REFERNECES}

1. Abdel-Azim S. Psychosocial and sexual aspects of female circumcision. African Journal of urological surgeon's association 2012; (19): 141 -142.

2. Shoaakazemi M, JavidM , Tazekand F, Rad ZS, Gholami M. Personality differences and sexual phobia in women .Social and behavioral science 2012; (69): 89- 94.

3. Desilva P. Sexual dysfunction in S.J.E Lindsay and G.E.Powell, The hand book of lineal and adult psychology. London and New York rout ledge 1995; (2): 199- 288 .

4. Jaafapour M ,Khani A, Khajavikhan J, Suhrabi Z. Female sexual dysfunction, prevalence and risk factor and diagnosis. Journal of clinical and diagnostic research 2013; 7 (12): 2877 -2880.

5. Caruso S, Rugolo S, Angello C, Intelisano G, Di Mari L, Cianci A. Sildenafil improve sexual functioning in premenopausal women with type 1 diabetes who are affected by sexual arousal disorder Fertility\& Sterility. 2006; 85(5): 1496- 1501.

6. Berman JR, Berman LA, Toler SM, Gill J, Haughie S. Safty and efficacy of sildenafil citrate for the treatment of female sexual arousal disorder.Journal of Urology.2003; 170(6): 2333- 2338.

7. Rosen R, Brown J, Heiman J, Leiblum S, Meston C, Shabsigh R, Ferguson D, D'Agostino R Jr. The Female Sexual Function Index (FSFI): a multidimensional self-report instrument for the assessment of female sexual function. J Sex Marital Ther. 2000; 26(2): 191- 208.

8. American Psychiatric Association(1994): DSMIV. Diagnostic and Statistical Manual of Mental Disorders, 4th ed. Washington DC: American Psychiatric Association.

9. Elnashar AM, El-Dien Ibrahim M, El-Desoky MM, Ali OM, El-Sayd Mohamed Hassan M. Female sexual dysfunction in Lower Egypt. BJOG. 2007;114(2):201 -6.

10. Spitzer M, Bhasin S, Travison TG, Davda MN, Stroh $\mathrm{H}$, Basaria S. Sildenafil increases serum testosterone levels by a direct action on the testes. Andrology 2013;1:913- 918 .

11. Leddy LS, Yang CC, Stuckey BG, Sudworth M, Haughie S, Sultana S, Maravilla KR. Influence of sildenafil on genital engorgement in women with female sexual arousal disorder. J Sex Med 2012; 9(10)2693-7.

12. Lo Monte G, Graziano A, Piva I, Marci R. Women taking the blue pill (sildenafil citrate) such big deal. Drug Design, Development and Therapy. Dove Press 2014; 8: 2251 -2254.

13. Das Gupta R, Wiseman OJ, Kanabar G, Fowler CJ, Mikol D. Efficacy of sildenafil in the treatment of female sexual dysfunction due to multiple sclerosis. J Urol 2004; 171(3): 1189 -1193.

14. Kaplan SA, Reis RB, Kohn IJ, Ikeguchi EF, Laor E, Te AE, Martins AC. Safety and efficacy of sildenafil in postmenopausal women with female sexual dysfunction. Urology 1999; (53):481 -486. 